\title{
Rice Farmer Risk Management by Cropping Pattern Diversification in Rural West Java:
} Motivation, Behavior, and Perception

\author{
Dadang Jainal Mutaqin ${ }^{1}$ and Koichi Usami ${ }^{2}$ \\ ${ }^{1}$ National Development Planning Agency (Bappenas), the Republic of Indonesia, Jakarta 10310, \\ Indonesia \\ ${ }^{2}$ Graduate School of International Development (GSID), Nagoya University, Nagoya 464-8601, Japan; \\ dadangjm@gmail.com; usami@gsid.nagoya-u.ac.jp
}

\begin{abstract}
The Indonesian government have implemented agricultural production cost insurance since 2015 called Asuransi Usaha Tani Padi (AUTP). It is an issue that the rate of farmer participation in the insurance is still low. As a challenge to increase participation, it becomes important to be aware of motivation, behavior, and perception that influence the practical risk management of farmers. This study investigated the relationship between cropping pattern diversification (as risk management) and factors such as motivation, behavior, and perception. Based on a field survey of 240 smallholder farmers in Garut District, West Java Province, these were the characteristics of farmers who practiced cropping pattern diversification: (1) high-risk perception (impact and probability); (2) risk-averse; and (3) economic motivation. The study revealed that approximately one-third of farmers had riskneutral and low-risk perceptions of whom approximately 70.7 percent practiced single cropping patterns. They may not adopt any risk- coping strategies unless they are aware of the risks that they face. Improving awareness about the negative impacts of risks on income from farming might encourage them to adopt risk-coping strategies for both on-farm risk coping (such as cropping pattern diversification) and off-farm risk-coping (such as agricultural insurance).
\end{abstract}

Keywords: Farmer risk management, motivation, risk behavior, risk perception, rural West Java

\section{ARTICLE INFO \\ Received: February 27, 2020 \\ Received in revised form: April 3, 2020 \\ Accepted: April 30, 2020}

doi: https://doi.org/10.46456/jisdep.v1i1.20
JISDeP - The Journal of Indonesia Sustainable Development Planning Published by Centre for Planners' Development, Education, and Training (Pusbindiklatren), Ministry of National Development Planning/ National Development Planning Agency (Bappenas), Republic of Indonesia
Address: Jalan Proklamasi 70,

Central Jakarta, Indonesia 10320

Phone: +62 $2131928280 / 3192828$

Fax: +622131928281

E-mail: pusbindiklatren@bappenas.go.id

Supported by Indonesian Development Planners

Association (PPPI) 


\section{Introduction}

In Indonesia, agricultural production has been threatened by the increase in risks due to climate change. National Disaster Management Authority (BNPB) (2017) reports that the number of drought and flood disasters had doubled from 2005 to 2015. According to the Minister of Agriculture (2017), there was a rise in the number of pest and disease occurrences from 2014 to 2017 . Moreover, because of El Nino Southern Oscillation, the risk in farming increased significantly. For example, when the dry season period was longer due to the El Nino, this made the wet season delayed (Supari et al., 2018) and accordingly resulted in failure in production of the wet season (Naylor et al., 2007).

As an innovative strategy to cope with risks, the Indonesian government had implemented agricultural production cost insurance for smallholder rice farmers since 2015 to reduce the adverse impact of risks (from climate change) on farmer prosperity. Unfortunately, the participation rate in 2016 was still approximately 23 percent of the target rice farmers (Jasindo, 2017). It implies issues of sustainable rice farming as well as food security.

Corbett (1988) and Zimmerman \& Carter (2003) stated that the first line of farmer efforts to reduce the adverse impacts of risks is modifying farming practices (on-farm strategy). One of the most important on-farm strategies is diversification of cropping patterns (Binswanger, 2012; Carter, 1997). To minimize risks in farming, farmers try to find the best combination of crops or cropping patterns that can maximize the output in a year (Hardaker et al., 2015). Encouraging more rice farmers to take up agricultural insurance, as far as agricultural insurance is an ex-ante risk coping strategy, it could be the first step to being practically aware of current risk management of farmers through cropping pattern diversification.

Farmers decide their cropping patterns based on their economic, technical, and social motivations for farming (Gasson, 1973; Greiner et al., 2009). In the process of selecting cropping patterns, risk perception plays an essential role. Farmers might have different perceptions about outcomes and risks when they select a certain type of innovation, including cropping pattern (Anderson et al., 1988). Another aspect is the farmer risk behavior. For instance, Feder (1980), Kabede (1992), and Moscardi \& de Janvry (1977) reported that risk behavior is associated with the level of technology adoption and the level of input allocated for production. Therefore, this study has the aim to clarifying the feature of farming motivation, behavior, and perception of farmers that underlie their practical cropping patterns in rural West Java, focusing on risk management.

\section{Methodology}

\subsection{Framework}

As shown in Figure 1, the selection of cropping patterns must be influenced by three factors: risk in farming, behavior towards risk, and motivation for farming. Risk in farming is perceived as a risk impact and risk probability (Rogers \& Prentice-Dunn, 1997).

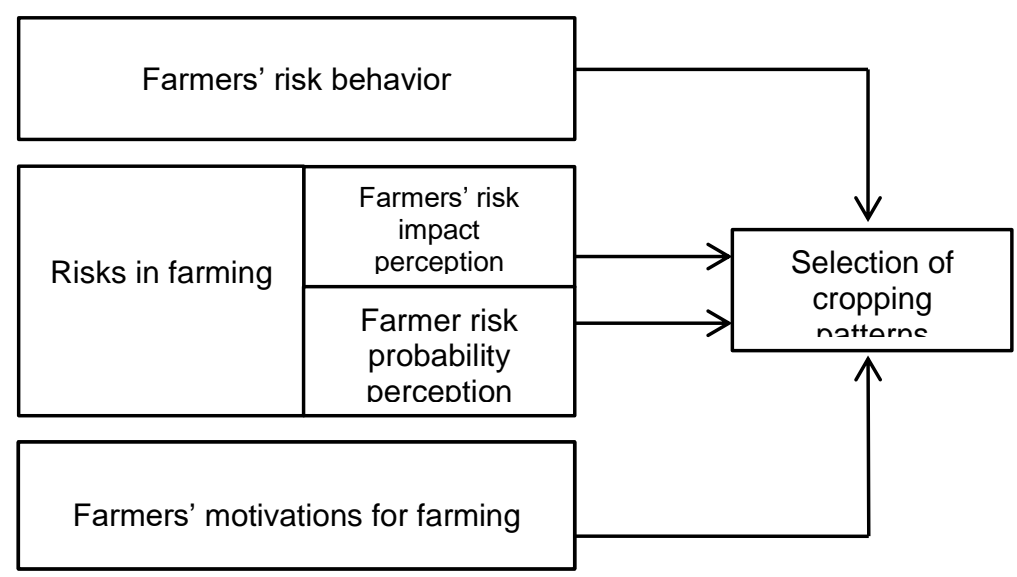

Figure 1. The framework used in the study

There are various risks in farming, which are grouped as production, price, personal/human capacity, government policy, and finance (Harwood et al., 1999; Hardaker et al., 2015). Production risk is related to 
soil fertility, water availability, and unpredictable weather (Loomis et al., 1971; DiFalco \& Chavas, 2009). The risk of price change/fluctuation in products and inputs is influential in the sustainability of farming, owing to high cost and low profits. Government policies and regulations, such as import policy, more taxes, and high products standards, might have adverse impacts on farming income (Goetz \& Zilberman, 2007). Personal/human risk is associated with poor health or injury. Financial risk is related to losing assets owing to production failure (Harwood et al., 1999).

Farmers have different preferences of risks in farming. Those who are risk-averse might try to reduce the adverse impact of risk exposure by taking risk-coping strategies (DiFalco \& Chavas, 2009; Menezes et al., 1980). The other two preferences are risk-neutral and risk-taker preferences.

It has been said that rational farmers pursue profit maximization in farming (Binswanger \& Rosenzweig, 2007; Gasson, 1973). However, farmer motivations for farming are not limited to profit maximization. They may include technical, cultural, and social motivations. As understood through indigenous knowledge or tradition, some crops are resilient to risks and indispensable to livelihood, which is likely to be one reason for willingness to cultivate crops with lower profit in cropping patterns. Some farmers might select a cropping pattern to technically adapt to biological and geographical conditions such as soil fertility and water availability (Leemans \& Born, 1994).

\subsection{Data Collection}

Garut District was selected as the study area (Figure 2). The district is one of the agricultural production centers in the West Java Province, located within 64 masl to 1,300 masl, where farmers produce paddy, corn, groundnuts, chili, mustard, cabbage, tomato, and others (CBS, 2016) because of its agro-climatic condition. Currently, the district has become one of the most vulnerable areas to disasters, especially floods and droughts (BNPB, 2017). Participation of farmers in agricultural production cost insurance in 2016 was one of the lowest among the districts in the province (Jasindo, 2017). ${ }^{1}$ There are two seasons in the study area: wet season and dry season. The wet season is from September to May, while the dry season is from June to August. The highest average monthly precipitation during the last five years in the West Java Province occurred in December (339.5 mm), while the lowest one in August (50.1 mm) (CBS, 2017).

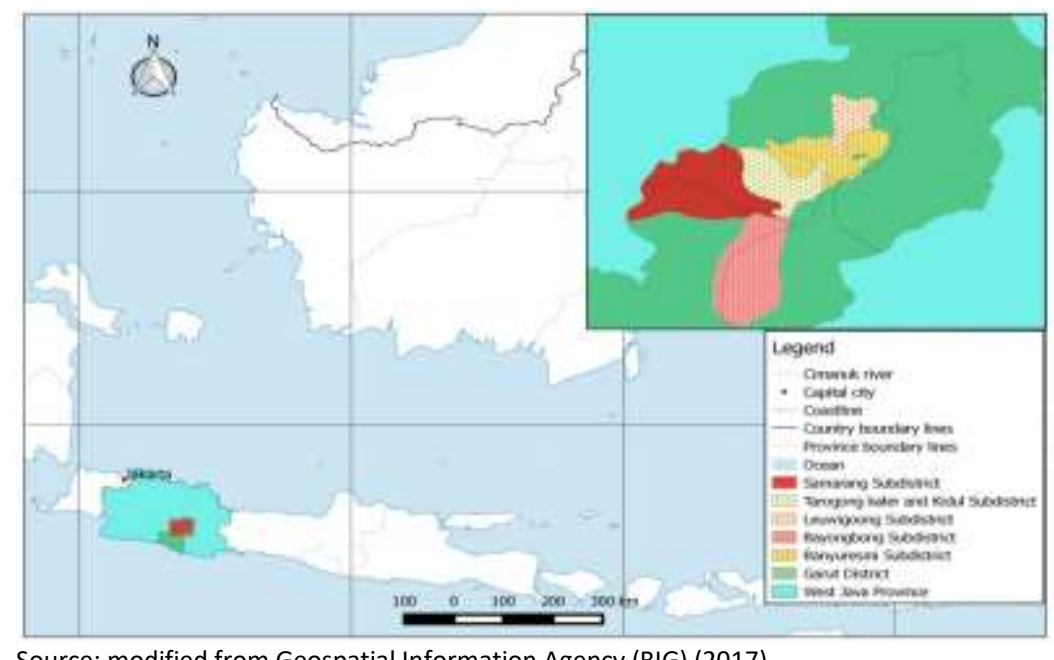

Source: modified from Geospatial Information Agency (BIG) (2017).

Figure 2. Location of study area

\footnotetext{
${ }^{1}$ Farmer participation in agricultural production cost insurance in 2017 in West Java Province was 36.9 percent from the target $(112,213$ ha out of 304,000 ha), while in Garut District was 24 percent from the target (1,920 ha out of 8,000 ha) (Ministry of Agriculture, 2018).
} 
Field surveys were first conducted from August to October 2017 and again in February 2018 in the northern part of Garut District. With a 95 percent confidence level $(Z=1.96), 50$ percent degree of variability, and 7.5 percent margin error, 240 farmers who had not yet utilized agricultural production cost insurance were selected by multistage cluster sampling. Six sub-districts ${ }^{2}$ were chosen from 21 subdistricts: two sub-districts each in the upstream, midstream, and downstream areas of the Cimanuk River in the district. These sub-districts are located in different altitudes: Bayombong (973 masl) and Semarang (815 masl) were in the upstream area, Tarogong Kaler (731 masl) and Tarogong Kidul (714 masl) were in the midstream area, and Banyuresmi (698 masl) and Leuwigoong (638 masl) were in the downstream area (CBS, 2016). From each sub-district, two villages were randomly selected, and 20 farmers were selected from each village. Face-to-face interviews were conducted with focus on motivation in farming, perceptions on faced risks, cropping patterns, and crops cultivated in each crop season during the period from 2012-2016. At the end of the interview, a game to measure risk behavior was played.

\subsection{Data Measurement}

\subsubsection{Motivation for Farming}

Farmers were asked to select their motivations for farming. They were allowed to mention a specific motivation that was not in the list of choices. There were eleven motivations in the list that could be divided into economic, cultural, and technical motivations (Table 1), and they could select one or more motivations.

Table 1. List of motivations

\begin{tabular}{ll}
\hline \multicolumn{1}{c}{ Type } & \multicolumn{1}{c}{ Motivation } \\
\hline Economic & Gain higher profit \\
& Attain higher yield \\
& Avoid commodity price fluctuation \\
& Avoid higher input cost \\
& Get a higher cash flow \\
& Follow market demand \\
\hline Cultural & Never change the crop grown \\
\hline Technical & Have knowledge and skill \\
& Reduce the occurrence of pests and diseases \\
& Reduce the impacts of environmental factor change \\
& Improve soil fertility \\
\hline
\end{tabular}

\subsubsection{Risk Behavior}

There are different approaches to measuring farmer risk behavior. For example, Mariano et al. (2012) use the existence of crop diversification as an indicator of risk behavior. Greiner et al. (2009) appllied the relative risk attitude method. Feder (1980) and Moscardi \& de Janvry (1977) took the amount of fertilizer used in production to measure the risk behavior characteristics. Schechter (2007) used a risk game (an economic experiment) to measure the risk behavior of indigenous people in rural areas. For the present study, the risk game was more appropriate for measuring farmers' risk behavior than the other approaches because diversification of cropping patterns involves decisions on financial asset allocations, which is similar to the nature of the risk game. Moreover, as an advantage, the risk game enables measurement of farmer risk behavior, specifically in the form of continuous data.

At the end of a face-to-face interview at the houses of farmers in the afternoon, after farming work was complete, the risk game was played as follows. Based on the risk game by Schechter (2007), the farmer is given real money of Rp. 30,000 (\$2.2). This is approximately two-thirds of the daily wage in the villages of the study (Rp. $50,000=\$ 3.7)$. The proportion of the value of money used in the game to the daily wage is almost equal to that in the risk game conducted by Schechter (2007). The daily wage is a meaningful reference for the risk game because the farmer will try to generate income for the day that is at least equal to the daily wage in the location. If the farmer could not get income on the day when the risk game was played, he or she was given $\mathrm{Rp} .30,000$, but this is still low compared to the daily wage of Rp. 50,000 (as the expected income of the day). In the risk game, the farmer has an opportunity to increase Rp. 30,000 to Rp. 50,000 by allocating some money as a bet. In this opportunity, the decision to bet or not depends on individual characteristics. If a farmer has a diminishing marginal utility of wealth,

${ }^{2}$ Sub-districts are subdivisions of a district. Sub-districts are divided into administrative villages. A province consists of several districts. 
he or she will avoid allocating the money as a bet. Conversely, if a farmer has an increasing marginal utility of wealth, he or she may try to allocate some amount of the money as a bet.

In the risk game, a farmer can bet the amount of 0 (no bet), 5000, 10,000, 15,000, 20,000, 25,000, or 30,000 . The betting farmer takes a piece of paper out of a transparent plastic bag, in which there are six pieces of paper numbered 1 to 6 . As shown in Table 2, suppose that he or she bets Rp. 30,000. If the number 6 is printed, he or she could gain Rp. 75,000, while if the number is 0 , he or she would lose the Rp. 30,000. In addition, for this study, based on how much of the Rp. 30,000 the farmer wished to bet, his or her risk behavior was categorized as risk-taker, risk- neutral, or risk-averse (Table 3).

Table 2. The rule of the risk game

\begin{tabular}{cll}
\hline $\begin{array}{c}\text { Number Taken in the } \\
\text { Game }\end{array}$ & \multicolumn{1}{c}{ Result of Bet } \\
\hline 1 & 0 & Meaning \\
2 & $0.5 \times$ money for the bet & Lain half of the money allocated for bet \\
3 & $1 \times$ money for the bet & Gain all of the money allocated for bet \\
4 & $1.5 \times$ money for the bet & Gain one and half of the money allocated for bet \\
5 & $2 \times$ money for the bet & Gain two times of the money allocated for bet \\
6 & $2.5 \times$ money for the bet & Gain two and half of the money allocated for bet
\end{tabular}

Source: Schechter (2007).

Table 3. Types of farmers' risk behavior

\begin{tabular}{ll}
\hline Value of Money Allocated for Bet & Type \\
\hline $0 \leq 10,000$ & Risk-averse \\
$10,000 \leq 20,000$ & Risk-neutral \\
$20,000 \leq 30,000$ & Risk-taker \\
\hline
\end{tabular}

\subsubsection{Risk Perception}

This study divides risk perception into two kinds: risk impact and risk probability. The former is the farmer perception of the impact of risk on his or her income from farming. The latter is the farmer perception of the probability of risk occurrence. Each perception was measured by a Likert scale, as presented in Table 4.

Table 4. Likert scale for risk perception measurement

\begin{tabular}{|c|c|}
\hline Perception & Likert Scale \\
\hline Risk impact & $1=$ very low, $2=$ low, $3=$ high, $4=$ very high \\
\hline Risk probability & $1=$ very low, $2=$ low, $3=$ high, $4=$ very high \\
\hline
\end{tabular}

\subsubsection{Diversification of Cropping Patterns}

This study focuses on the diversification of cropping patterns as a farming practice to understand farmer risk management in farming. This is because farmers try to minimize the adverse impacts of risks by adjusting cropping patterns (O'Donoghue et al., 2005; Mandal, 2010). There are several methods of estimating the degree of diversification: Herfindahl Index, Simpson Diversity Index, Ogive Index, Entropy Index, Modify Entropy Index, and Composite Entropy Index (Chand \& Ramesh, 1996; Kelley \& Ryan, 1995; Shiyani \& Pandya, 1998). Since the degree of diversification can be captured by incorporating the number of crops planted and the proportion of area cultivated for each crop in a cropping pattern, this study utilized the Composite Entropy Index (CEI) to measure the diversification of the cropping patterns. The following is the equation of CEI:

$$
\mathrm{CEI}=\left[-\sum_{i=1}^{N} P_{i} \log \mathrm{N} P_{i}\right] \times\left[1-\frac{1}{N}\right]
$$


where $N$ is the number of crops planted, and $P_{i}$ is the proportion of $i^{\text {th }}$ crop to the total cropped area. The value of $\mathrm{CEI}$ ranges between 0 and 1 . For example, the CEI of two rice crops on the paddy field is 0 , since the number of the crop planted is only 1.

\subsection{Data Analysis}

In this study, Cluster Analysis (CA) was conducted to identify the groups of farmers with similar characteristics based on the value of $\mathrm{CEI}$, motivation for farming, risk behavior, and risk perception. It was also used to describe the overall association between motivation for farming, risk behavior, risk perception, and CEI. Meanwhile, Principal Component Analysis (PCA) was applied to investigate the common factors of motivation for farming and risk perception

\section{Results and Discussions}

\subsection{Farmers' Characteristics}

As shown in Table 5, the average age of farmers was 51.9 years old, and the average level of education was approximately 7.5 years. The majority (90.4 percent) of farmers were male. The average per capita expenditure and asset value were Rp. 9.7 million/year and Rp. 98.3 million respectively. Approximately one-third of farmers had a bank account. The highest proportion of landholding arrangement was 48.8 percent of sharecropping, followed by owner ( 45.8 percent) and rent in cash (5.4 percent). On average, farmers managed 0.43 ha of farmland. The percentage of farmers who implemented cropping pattern diversification was 54.6 percent.

Table 5. Summary of farmer characteristics

\begin{tabular}{lc}
\hline Variable & Average, Percentage \\
\hline Age of farmer (year) & 51.9 \\
Education of farmer (year) & 7.5 \\
Gender (percentage of male) & 90.4 \\
\hline Per capita expenditure (Rp mil/year) & 9.7 \\
Asset value (Rp mil) & 98.3 \\
Bank account ownership (\%) & 31.7 \\
\hline Farmland size (ha) & 0.43 \\
Type of farmland & \\
Irrigated farmland (\%) & 77.1 \\
Rain-fed farmland (\%) & 22.9 \\
Landholding & \\
Owner (\%) & 45.8 \\
Sharecropping (\%) & 48.8 \\
Rent in cash (\%) & 5.4 \\
Farmers with the diversification of & 54.6 \\
cropping patterns (\%) &
\end{tabular}

\subsection{Cropping Patterns}

As shown in Table 6, five kinds of cropping patterns were practiced by farmers in three cropping seasons: (a) paddy-paddy-paddy; (b) paddy-paddy-horticulture; (c) paddy-horticulture- paddy; (d) paddyhorticulture-horticulture; and (e) paddy/horticulture-paddy/horticulture-paddy/ horticulture. The number of cropping patterns practiced by a farmer during the last five years ranged between one and four.

One hundred and nine farmers (45.4 percent) practiced just a single cropping pattern of paddypaddy-paddy. There were 63 farmers (26.3 percent) who practiced a combination of three cropping patterns by selecting three out of four cropping patterns. The majority (58) of these farmers selected the combination of paddy-paddy-paddy, paddy-paddy-horticulture, and paddy-horticulture-paddy. The value of CEI for the combination of three cropping patterns ranged from 0.28 to 0.56 . There were 42 farmers (17.5 percent) who selected two out of four cropping patterns, and the value of CEI ranged from 0.17 to 0.46. The majority (32) of these farmers selected paddy-paddy-paddy combined with paddy-paddyhorticulture. In contrast, there were fewer farmers (26 farmers, 10.8 percent) who practiced four out of five cropping patterns, and the value of CEI ranged from 0.29 to 0.61 . In this group, the majority (20) of 
these farmers practiced the combinations of paddy-paddy-paddy, paddy-paddy-horticulture, paddyhorticulture-paddy, and paddy-horticulture-horticulture.

As for the preference of cropping patterns by farmers of among the downstream, midstream, and upstream areas, there were differences in the practiced cropping patterns. (1) In the downstream area, the majority of farmers practiced one cropping pattern; $(2)$ in the midstream area, the majority of farmers practiced three cropping patterns (32 farmers, 40 percent) and one cropping pattern ( 27 farmers, 33.7 percent); and (3) in the upstream area, the majority of farmers practiced one cropping pattern. The percentage of farmers who practiced four cropping patterns compared to those in the other areas is the highest.

Table 6. CEI and the number of farmers by cropping patterns

\begin{tabular}{|c|c|c|c|c|c|c|c|c|c|c|c|}
\hline \multirow{2}{*}{$\begin{array}{l}\text { Number of } \\
\text { Cropping } \\
\text { Patterns }\end{array}$} & \multicolumn{5}{|c|}{$\begin{array}{c}\text { Cropping Pattern } \\
\text { Selected }\end{array}$} & \multirow[t]{2}{*}{ CEI } & \multicolumn{5}{|c|}{ Number of Farmers } \\
\hline & $\mathrm{a}$ & $\mathrm{b}$ & c & d & e & & $\begin{array}{l}\text { Down- } \\
\text { stream }\end{array}$ & $\begin{array}{c}\text { Mid- } \\
\text { stream }\end{array}$ & $\begin{array}{c}\text { Up- } \\
\text { stream }\end{array}$ & Total & $\%$ \\
\hline \multirow[t]{10}{*}{1} & + & & & & & 0 & 46 & 27 & 36 & 109 & 45.4 \\
\hline & + & + & & & & $0.17-0.46$ & 10 & 17 & 5 & 32 & 13.3 \\
\hline & + & & + & & & $0.17-0.44$ & 2 & 1 & 1 & 4 & 1.7 \\
\hline & + & & & + & & $0.28-0.44$ & 3 & 1 & 2 & 6 & 2.5 \\
\hline & + & + & + & & & $0.28-0.56$ & 16 & 32 & 10 & 58 & 24.2 \\
\hline & + & + & & + & & $0.28-0.51$ & 1 & 0 & 4 & 5 & 2.1 \\
\hline & + & + & + & + & & $0.29-0.59$ & 1 & 2 & 17 & 20 & 8.3 \\
\hline & + & + & + & & + & $0.44-0.58$ & 0 & 0 & 2 & 2 & 0.8 \\
\hline & + & + & & + & + & $0.44-0.51$ & 1 & 0 & 2 & 3 & 1.3 \\
\hline & & + & + & + & + & 0.61 & 0 & 0 & 1 & 1 & 0.4 \\
\hline
\end{tabular}

Note: $+=$ cropping pattern selected; $a$ = paddy-paddy-paddy; $b=$ paddy-paddy- horticulture; $c$ = paddy-horticulturepaddy; $d$ = paddy-horticulture-horticulture; $e=$ paddy/horticulture-paddy/horticulture-paddy/horticulture.

\subsection{Farmers' Motivation}

As shown in Figure 3, the main motivations for selecting crops were "Gain higher profit" (125 farmers, 52.1 percent), "Never change the crop planted" (109 farmers, 45.4 percent), "Attain higher yield" (97 farmers, 40.4 percent), and "Avoid commodity price fluctuation" (92 farmers, 38.3 percent). As a whole, economic objectives were the major motivation of farmers.

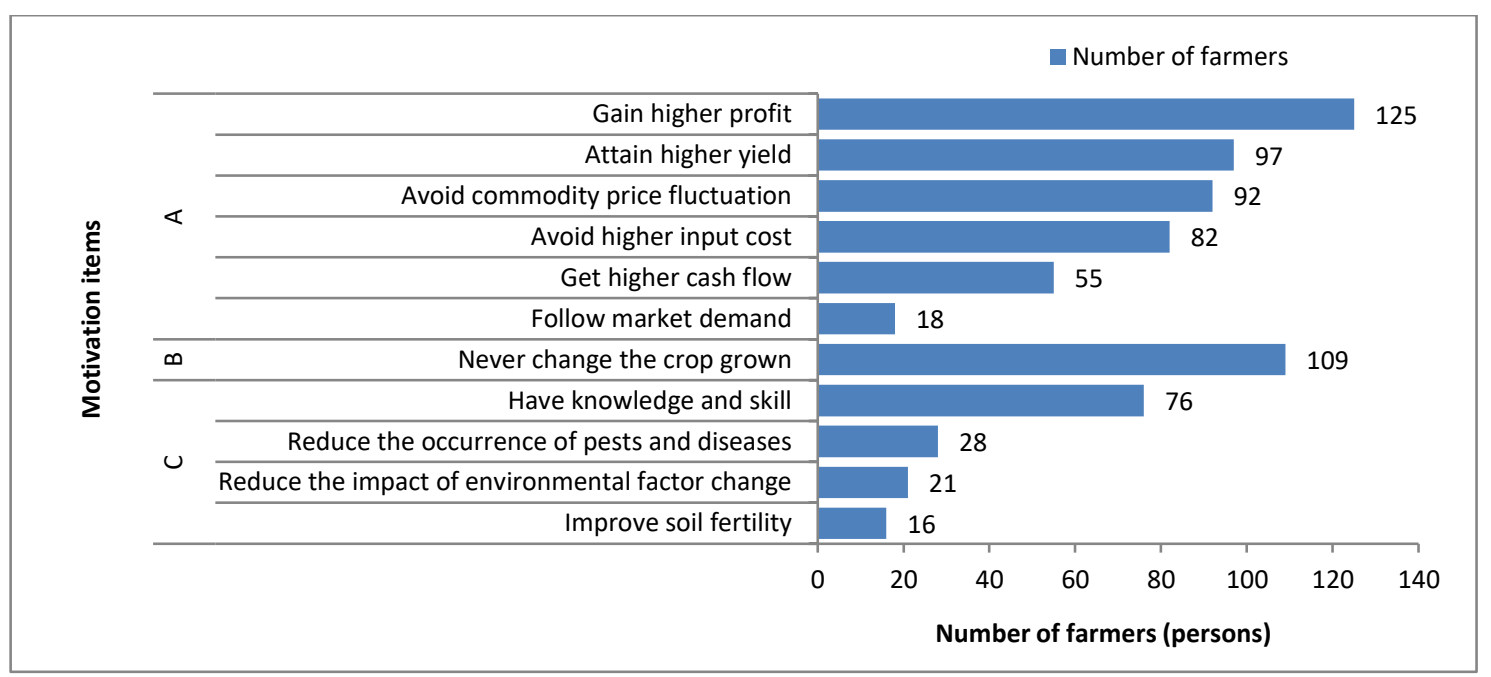

Note: $\mathrm{A}=$ economic motivation; $\mathrm{B}=$ cultural motivation; $\mathrm{C}=$ technical motivation.

\section{Figure 3. The rank of farmers' motivations for farming}

As for the range of motivations, the majority (208 farmers, 86.7 percent) had more than one motivation. There were approximately 63 combinations of farmers' motivations. Table 7 presents the top 10 farmer motivations (of 147 farmers, 61.3 percent). There were differences in farmer motivations among the downstream, midstream, and upstream areas. In the downstream area, the majority of farmers (18 farmers, 22.5 percent) were driven by three economic motivations: "Gain higher profit + 
Attain higher yield + Avoid commodity price fluctuation". In the midstream area, two combinations of two motivations, "Avoid higher input cost + Never change crop grown" and "Avoid higher input cost + Have knowledge and skill", motivated the majority of farmers, approximately 14 farmers (17.5 percent) and 13 farmers (16.2 percent), respectively. Meanwhile, in the upstream area, the majority of farmers (19 farmers, 23.7 percent) were driven by cultural motivation ("Never change crop grown") and a combination of four economic motivations (16 farmers, 20 percent): "Gain higher profit + Attain higher yield + Avoid commodity price fluctuation + Get higher cash flow". As a whole, the combination of farmers' motivation for farming was diversified, but the core motivation was economic, while the single motivation for farming was limited to "Never change crop grown".

Table 7. Top 10 motivation combinations

\begin{tabular}{|c|c|c|c|c|c|c|c|c|c|c|c|c|c|c|c|c|}
\hline \multirow{3}{*}{ No } & \multicolumn{11}{|c|}{ Motivation } & \multirow{2}{*}{\multicolumn{3}{|c|}{ Location }} & \multirow{2}{*}{\multicolumn{2}{|c|}{ Total }} \\
\hline & \multicolumn{6}{|c|}{ Economic } & \multirow{2}{*}{$\begin{array}{c}\text { Cultural } \\
\text { NC }\end{array}$} & \multicolumn{4}{|c|}{ Technical } & & & & & \\
\hline & $\mathrm{HP}$ & $\mathrm{HY}$ & $\mathrm{CP}$ & IC & $\mathrm{CF}$ & MD & & KS & PD & SF & $\mathrm{EC}$ & $\mathrm{D}$ & $M$ & $U$ & $\mathrm{~N}$ & $\%$ \\
\hline 1 & & & & & & & + & & & & & 11 & 2 & 19 & 32 & 13.3 \\
\hline 2 & + & + & + & & & & & & & & & 18 & 4 & 4 & 26 & 10.8 \\
\hline 3 & & & & + & & & + & & & & & 7 & 14 & 0 & 21 & 8.8 \\
\hline 4 & & & & + & & & & + & & & & 4 & 13 & 0 & 17 & 7.1 \\
\hline 5 & + & + & + & & + & & & & & & & 0 & 0 & 16 & 16 & 6.7 \\
\hline 6 & & & & & & & + & + & & & & 0 & 12 & 1 & 13 & 5.4 \\
\hline 7 & + & + & & & & & + & & & & & 7 & 0 & 0 & 7 & 2.9 \\
\hline 8 & & & & & & & + & & + & & & 5 & 1 & 0 & 6 & 2.5 \\
\hline 9 & + & & + & & + & & & & & & & 0 & 0 & 5 & 5 & 2.1 \\
\hline 10 & + & + & + & & & & & + & & & & 0 & 3 & 1 & 4 & 1.7 \\
\hline
\end{tabular}

Note: + = motivation selected; $\mathrm{N}=$ number of farmers; $\mathrm{HP}=$ Gain higher profit; $\mathrm{HY}=$ Attain higher yield; $\mathrm{CP}=$ Avoid commodity price fluctuation; $\mathrm{IC}=$ Avoid higher input cost; $\mathrm{CF}=$ Get higher cash flow; $\mathrm{MD}=$ Follow market demand; $\mathrm{NC}=$ Never change crop grown; KS = Have knowledge and skill; PD = Reduce pests and diseases; SF = Improve soil fertility; EC $=$ Reduce the impacts of environmental change; $\mathrm{D}=$ Downstream; $\mathrm{M}=$ Midstream; $\mathrm{U}=$ Upstream.

Figure 4 presents the top three farmer motivations by the number of practiced cropping patterns. There were several findings:

(1) Cultural motivation ("Never change crop grown") was the main motivation of farmers who practiced one or two cropping patterns. Moreover, these two groups had economic motivation as one of the top three motivations: "Gain higher profit". The difference between farmers who practiced one or two cropping patterns was that farmers who practiced two cropping patterns had technical skill motivation ("Have knowledge and skill"), while farmers who practiced one cropping pattern did not have this motivation.

(2) The economic motivation was the main motivation for farmers who practiced three or four cropping patterns, with "Gain higher profit", "Attain higher yield", and "Avoid commodity price fluctuation" being the top three motivations. The difference between the two groups was that farmers practicing three cropping patterns were more likely to select "Gain higher profit" and "Attain higher yield" as their motivation. Meanwhile, farmers practicing four cropping patterns almost had equal proportions in selecting the three motivations ("Gain higher profit", "Attain higher yield", and "Avoid commodity price fluctuation").

In general, it can be concluded that the number of cropping patterns practiced has a relationship with farmer motivation. For example, "Have knowledge and skill" became an essential motivation for farmers to implement cropping pattern diversification. If farmers have knowledge and skill, they might change their farming practices from one cropping pattern to two cropping patterns. 


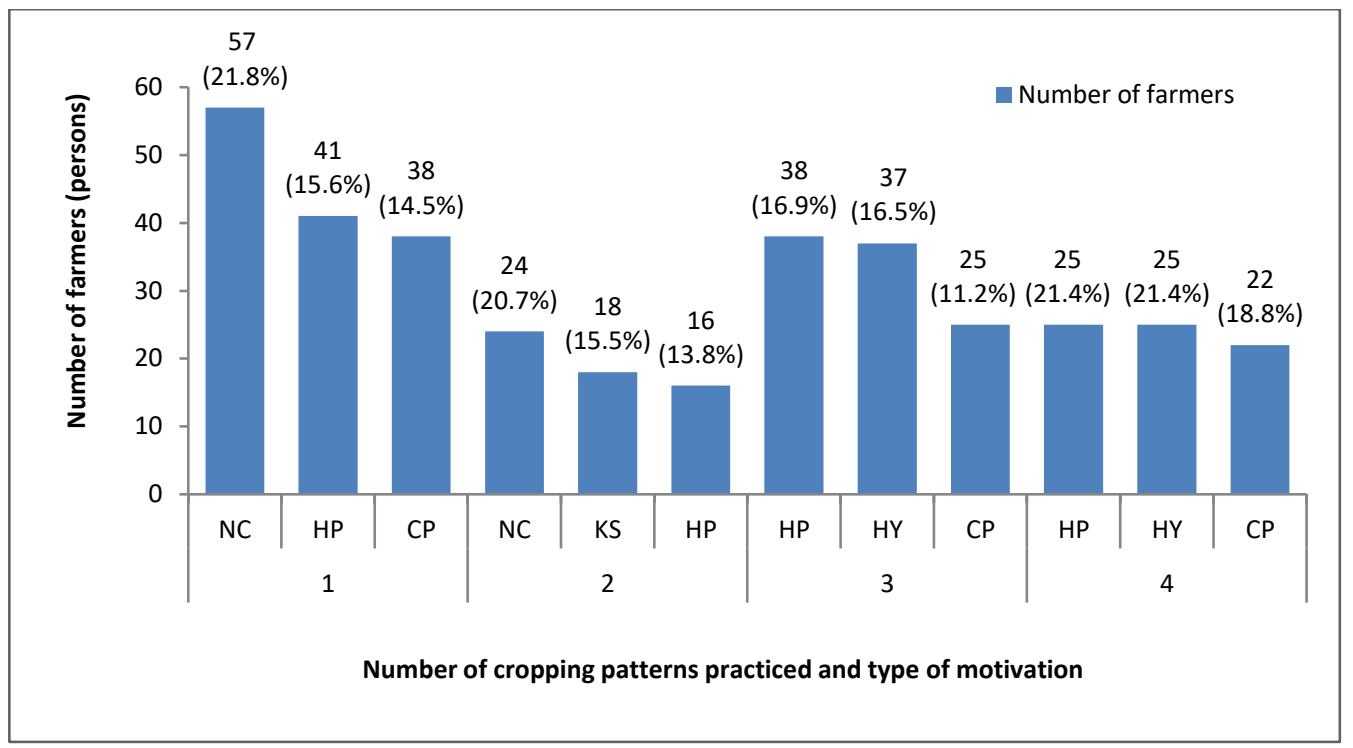

Note: $\mathrm{HP}=$ Gain higher profit; $\mathrm{HY}=$ Attain higher yield; $\mathrm{CP}=$ Avoid commodity price fluctuation; NC = Never change crop grown; KS = Have knowledge and skill. The percentage was calculated by dividing the number of farmers selected motivation by the number of farmers.

Figure 4. Main Farmer motivations for farming by the number of cropping patterns

\subsection{Farmers' Risk Behavior}

As shown in Table 8, almost half of the farmers (52.9 percent) had risk-averse behavior. On average, they betted only Rp. 7,142 (24 percent) out of Rp. 30,000, and consequently reduced the Rp. 30,000 to Rp. 28,704 owing to less gain from the risk game, while risk-taker farmers (only 8.8 percent) betted Rp. 25,629 out of Rp. 30,000 (85.4 percent) and increased the Rp. 30,000 to Rp. 36,038 owing to much gains from the risk game. As for risk-neutral farmers (38.3 percent), they betted Rp. 18,750 out of Rp. 30,000, but they had a little gain from the risk game (Rp. 31,848 from Rp. 30,000). On average, risk-taker farmers could increase their value of money compared to risk-averse and risk-neutral farmers. Risk-averse farmers might not increase their value of money because their willingness to bet in a high-risk game was very low. It is of interest that the value of money for risk-neutral farmers did not increase significantly compared to risk- taker. The percentages of the risk-taker, risk-neutral, and risk-averse farmers who could increase the value of the money were 62 percent, 83 percent, and 41 percent, respectively.

As shown in Figure 5, it can be seen that (1) risk-averse farmers diversified cropping patterns; (2) risktaker farmers remained with a single cropping pattern of triple rice crops; and (3) risk-neutral farmers had a diverse number of practiced cropping patterns, but the majority practiced the single cropping pattern of triple rice crops.

Table 8. Result of the risk game

\begin{tabular}{ccccccc}
\hline $\begin{array}{c}\text { Risk } \\
\text { Behavior }\end{array}$ & $\begin{array}{c}\text { Average Money } \\
\text { Allocated for } \\
\text { Betting (Rp) }\end{array}$ & $\begin{array}{c}\text { Number of } \\
\text { Farmers (\%) }\end{array}$ & $\begin{array}{c}\text { Average Money } \\
\text { Gained from } \\
\text { Betting (Rp) }\end{array}$ & $\begin{array}{c}\text { Average Money } \\
\text { Owned after } \\
\text { Betting (Rp) }\end{array}$ & $\begin{array}{c}\text { Number of Farmers with the } \\
\text { Amount of Money Rp30,000 and } \\
\text { Rp30,000 }<\text { after Betting }\end{array}$ & $\begin{array}{c}\text { Rp 30,000 } \\
\text { Rp30,000< }\end{array}$ \\
\hline Risk-taker & 25,629 & $21(8.8 \%)$ & 31,667 & 36,038 & $8(38 \%)$ & $13(62 \%)$ \\
\hline $\begin{array}{c}\text { Risk- } \\
\text { neutral }\end{array}$ & 18,750 & $92(38.3 \%)$ & 20,597 & 31,848 & $16(17 \%)$ \\
\hline Risk-averse & 7,142 & $127(52.9 \%)$ & 5,846 & 28,704 & $75(59 \%)$ & $76(83 \%)$ \\
\hline
\end{tabular}




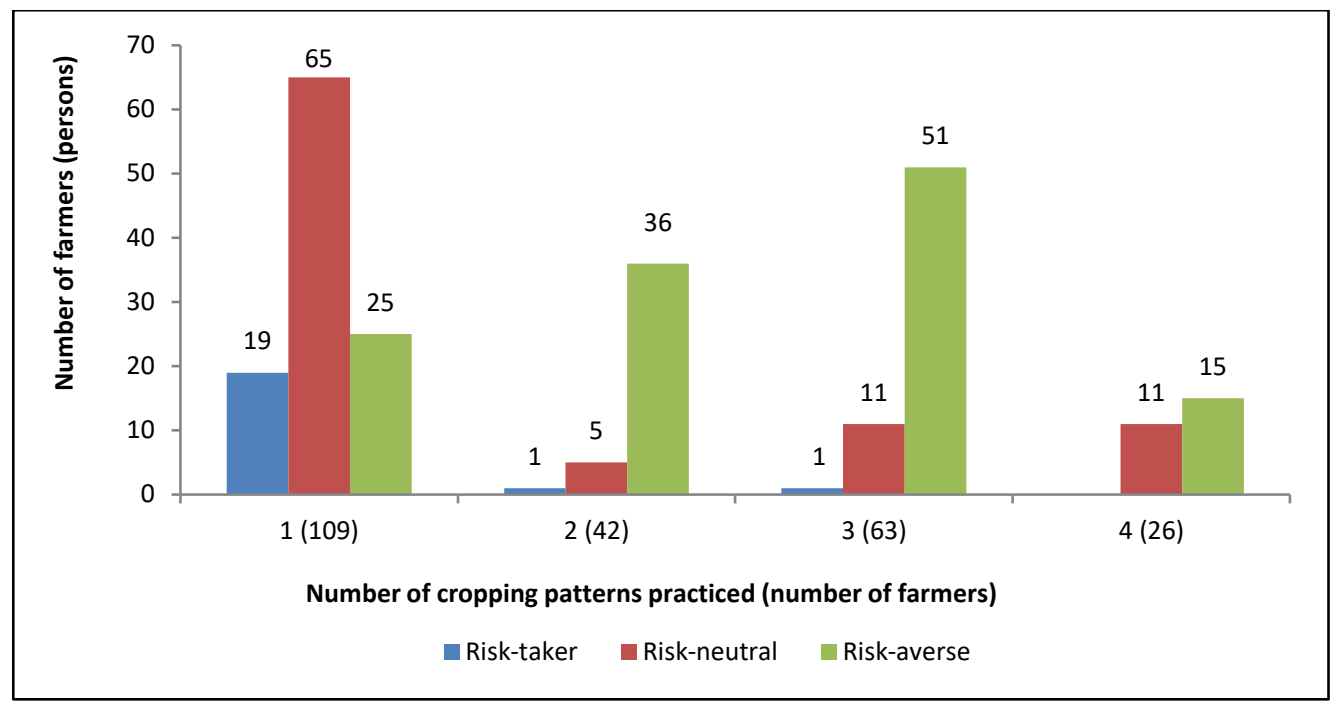

Figure 5. Farmers' risk behavior by the number of cropping patterns

\subsection{Farmers' Risk Perception}

As shown in Figures 6 and 7, as far as top five risk perceptions were concerned, there were some interesting findings on farmer risk perception (impact and probability) in the downstream, midstream, and upstream areas:

(1) Risk impact perception

(a) "Yield variability", "Commodity price", "Pests and diseases", and "Water scarcity" were common risks that had impacts on farming income in the downstream, midstream, and upstream areas.

(b) "Yield variability", "Commodity price', "Pests and diseases", and "Water scarcity" had impacts on farmers in the upstream area compared to farmers in downstream and midstream.

(c) "Government policy" was a common risk that impacted on farming income in the downstream and midstream areas.

(d) "Soil fertility" risk was limited to farmers in the upstream area.

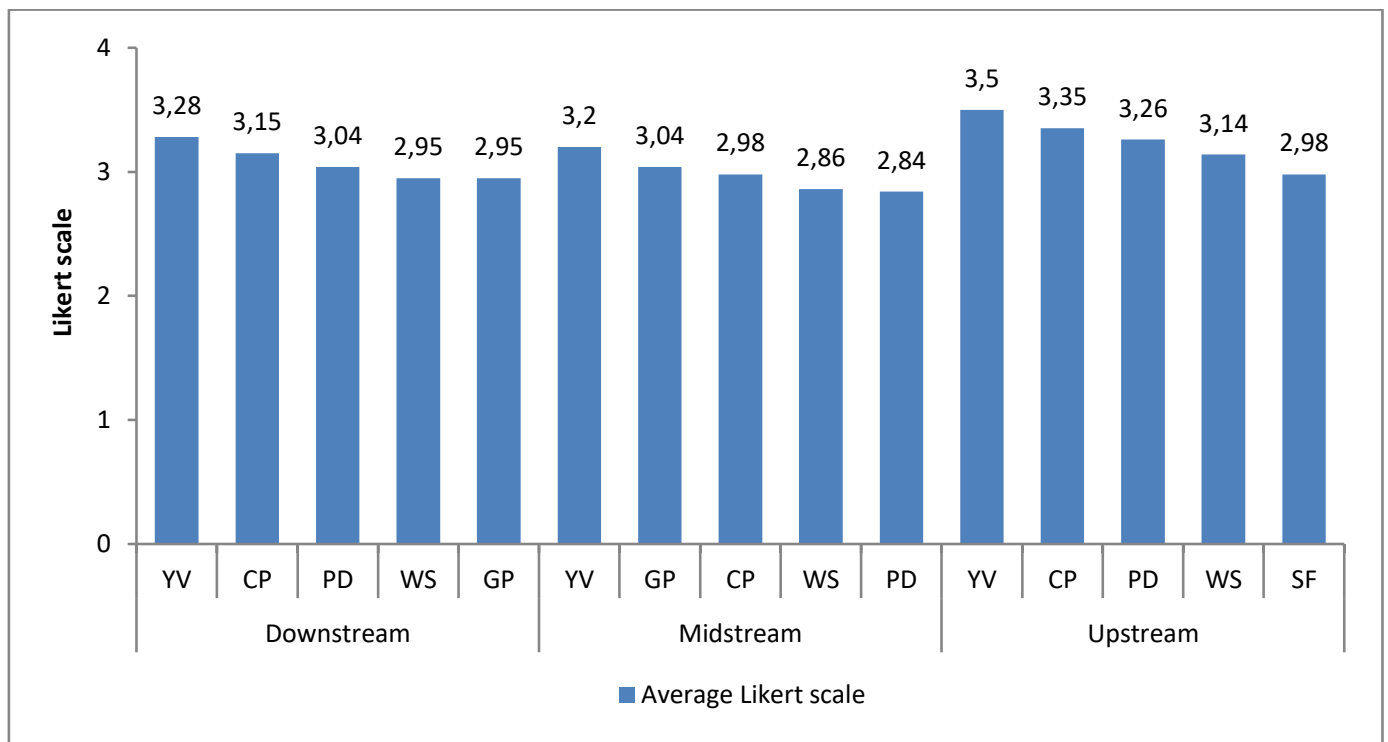

Note: $\mathrm{YV}=$ Yield variability; $\mathrm{PD}=$ Pests and diseases; $\mathrm{CP}=$ Commodity price fluctuation; $\mathrm{WS}=$ Water scarcity; $\mathrm{GP}=$ Government policy; SF = Soil fertility; $1=$ very low; 2 = low; 3 = high; 4 = very high.

Figure 6. Risk impact perception 
(2) Risk probability perception

(a) "Yield variability", "Commodity price', and "Pests and diseases" were common risks that occurred in the downstream, midstream, and upstream areas.

(b) "Yield variability" was the risk with the highest probability to occur both in the downstream and upstream areas, while in the midstream area was "Commodity price fluctuation".

(c) "Water scarcity" and "Government policy" were risks that commonly occurred in the downstream and midstream areas.

(d) "Pollination failure" and "Soil fertility" were limited to farmers in the upstream area.

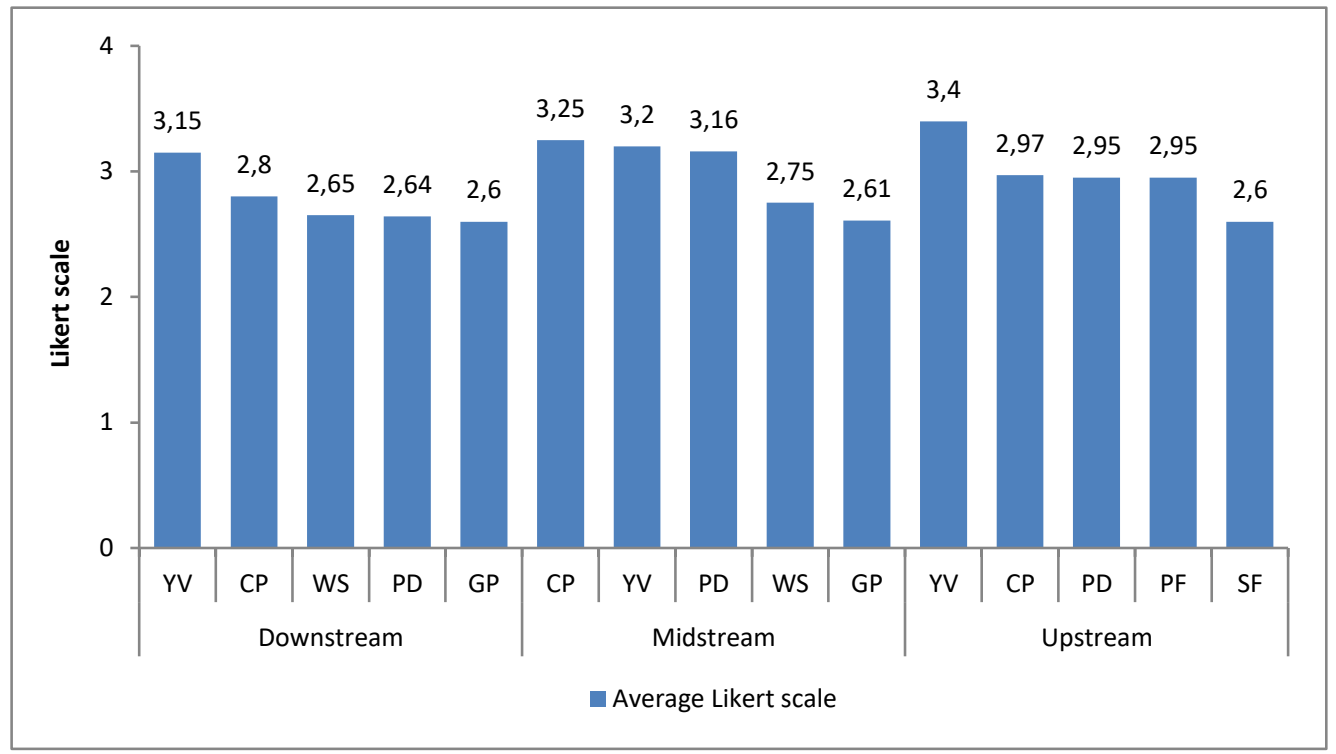

Note: $\mathrm{YV}=$ Yield variability; $\mathrm{PD}=$ Pests and diseases; $\mathrm{CP}=$ Commodity price fluctuation; $\mathrm{WS}=$ Water scarcity; $\mathrm{GP}=$ Government policy; $\mathrm{PF}=$ Pollination failure; SF = Soil fertility; $1=$ very low; 2 = low; 3 = high; $4=$ very high

Figure 7. Risk probability perception

It could be concluded that the type of risks perceived by farmers in the midstream and downstream areas was almost similar. Risks that were limited to farmers in the upstream area were "Pollination failure" and "Soil fertility".

The top five risk impact and risk probability perceptions are presented by the number of cropping patterns in Figures 8 and 9. As far as the top five perceptions were concerned, the following are the interesting findings:

(1) Risk impact perception

(a) Farmers who practiced single cropping pattern (paddy-paddy-paddy) had an average Likert scale score of less than 2.5 (excluding 2.57 of "Yield variability"), while it was greater than 3.5 for the other groups (farmers practicing two, three, and four cropping patterns).

(b) The average score of the Likert scale of risk impact perception of farmers who practiced four cropping patterns for each type of risk was higher compared to farmers practicing other cropping patterns.

(c) "Yield variability", "Commodity price", and "Pests and diseases" risks were risks that had impacts on all groups.

(d) "Water scarcity", "Government policy", and "Capital return" were risks that had impacts on farming income to three out of four farmer groups. "Farmers' skill" risk impacted on farmers who practiced single cropping pattern.

(e) "Yield variability" was the top risk that impacted on farming income for each of the farmer groups. 


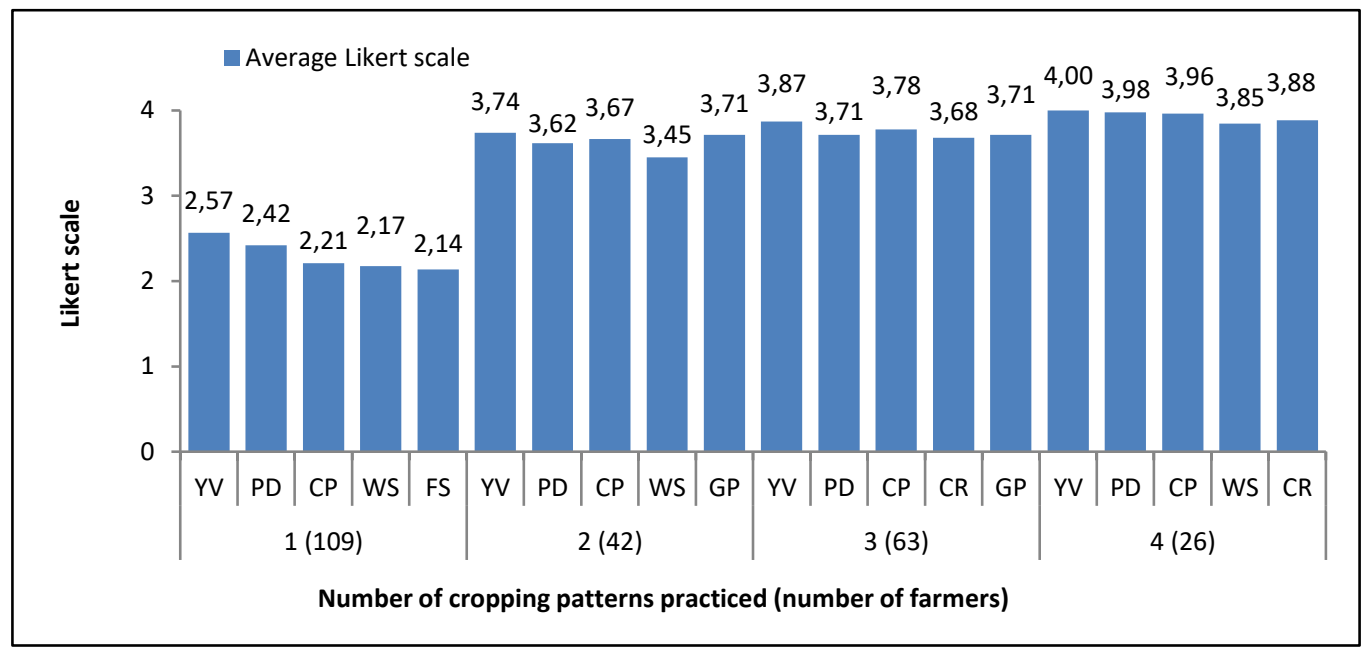

Note: $\mathrm{YV}=$ Yield variability; $\mathrm{PD}=$ Pests and diseases; $\mathrm{CP}=$ Commodity price; $\mathrm{WS}=$ Water scarcity; FS = Farmers' skill; $\mathrm{GP}=$ Government policy; $\mathrm{CR}=$ Capital return; $1=$ very low; 2 = low; 3 = high; 4 = very high.

Figure 8. Farmers' risk impact perception by the number of cropping patterns

(2) Risk probability perception

(a) Farmers who practiced a single cropping pattern (paddy-paddy-paddy) had an average Likert scale score of less than 2.0 (excluding 2.51 of yield variability), while it was greater than 3.5 for the other groups.

(b) "Yield variability" and "Commodity price fluctuation" were risks that had a probability to occur in all groups.

(c) "Pests and diseases", "Water scarcity", "Government policy", "Capital return", and "Soil fertility" were risks that commonly occurred for two out of four farmer groups. "Farmers' skill" was limited to the farmer group who practiced single cropping pattern (paddy-paddy-paddy), and "Asset" was limited to farmers who practiced two cropping patterns.

(d) The occurrence of the "Soil fertility" risk was common to farmers who practiced three or four cropping patterns.

(e) "Yield variability" was the top risk to occur for all groups.

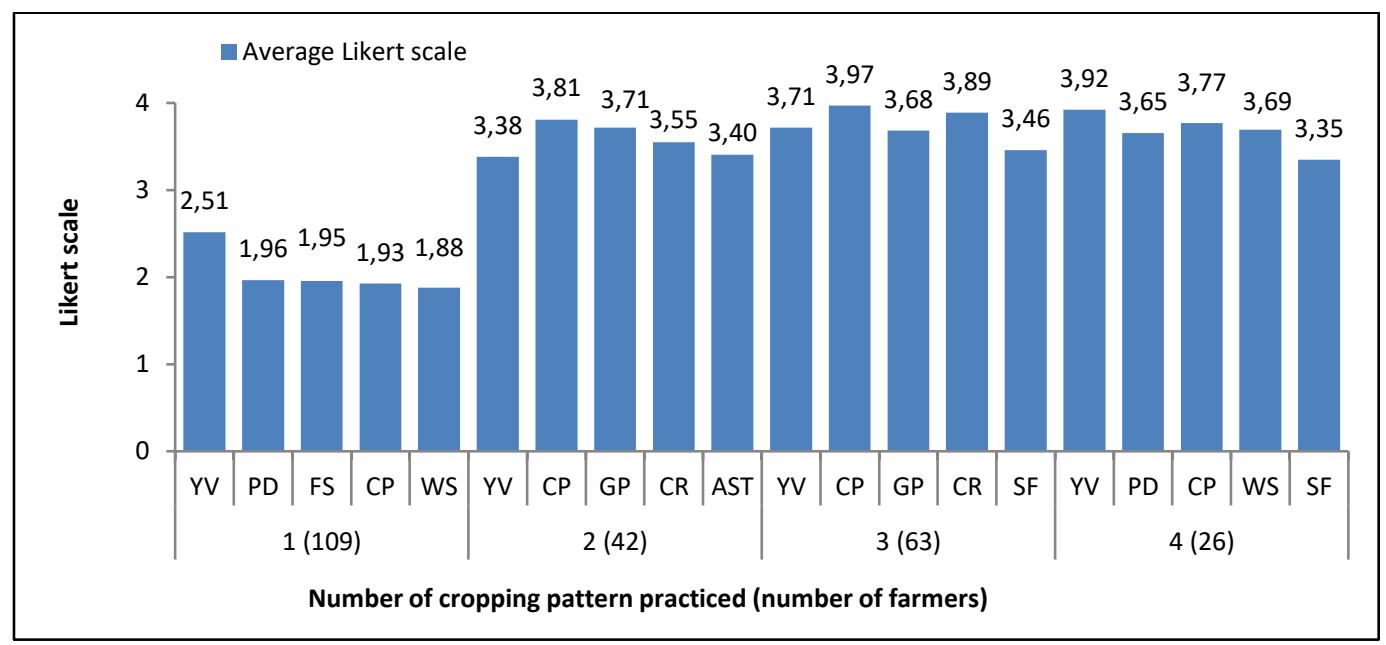

Note: $\mathrm{YV}=$ Yield variability; $\mathrm{PD}=$ Pests and diseases; FS = Farmers' skill; $\mathrm{CP}=$ Commodity price; $\mathrm{WS}=$ Water scarcity; $\mathrm{GP}=$ Government policy; $\mathrm{CR}=$ Capital return; $\mathrm{AST}=$ Asset; SF = Soil fertility; 1 = very low; 2 = low; 3 = high; $4=$ very high.

Figure 9. Farmer risk probability perception by the number of cropping patterns

On the whole, there was a relationship between the number of cropping patterns practiced by farmers and their risk perception. Farmers who diversified their cropping patterns had a higher risk impact and risk probability perception than those practicing a single cropping pattern (paddy-paddy-paddy). 
However, regarding risks of comparatively high interest, there was a slight difference between the risk impact perception and the risk probability perception of farmers practicing cropping pattern diversification. There were risks that were not considered as the top five risks in terms of impacts by farmers practicing cropping pattern diversification, but they were considered as one of the top five risks that had a high probability to occur; these are soil fertility and asset risk.

\subsection{Association of Motivation for Farming, Risk Behavior, Risk Perception, and Cropping Patterns}

As shown in Table 9, the association between motivation for farming, risk behavior, and risk perception behind cropping pattern diversification can be explained below:

(1) Risk behavior and risk perception (impact and probability) might influence the decision of farmers to practice a single cropping pattern or two cropping patterns. Although they had similar motivations (cultural and economic), the majority of farmers who practiced single cropping pattern had risk-neutral and risk-averse behavior, while those who practiced two cropping patterns had riskaverse behavior. Regarding risk perception, the impact and probability of risk of farmers who practiced a single cropping pattern (Likert score 2.0-2.5) were lower than the farmers who practiced two cropping patterns (Likert score $>2.5$ ).

(2) Motivation for farming, risk behavior, and risk perception might influence the decision of farmers to practice a single cropping pattern or three cropping patterns. Farmers who practiced a single cropping pattern were driven by cultural and economic motivations, and the majority of them were risk-neutral and risk-averse, while farmers who practiced three cropping patterns were driven by economic and technical motivations, and the majority of them were risk-averse. They were different in risk impact perception and risk probability perception. Farmers who practiced single cropping pattern argued that "Water scarcity" and "Farmer skills" had impacts on income from farming, and the probability of "Pests and diseases", "Water scarcity", and "Farmer skills" risks to occur was high, while farmers who practiced three cropping patterns argued that "Capital return" and "Government policy" had impacts on income from farming, and the probability of "Government policy", "Capital return", and "Soil fertility" risk to occur was high.

Table 9. Major motivations for farming, risk behavior, and risk perception by the number of cropping patterns

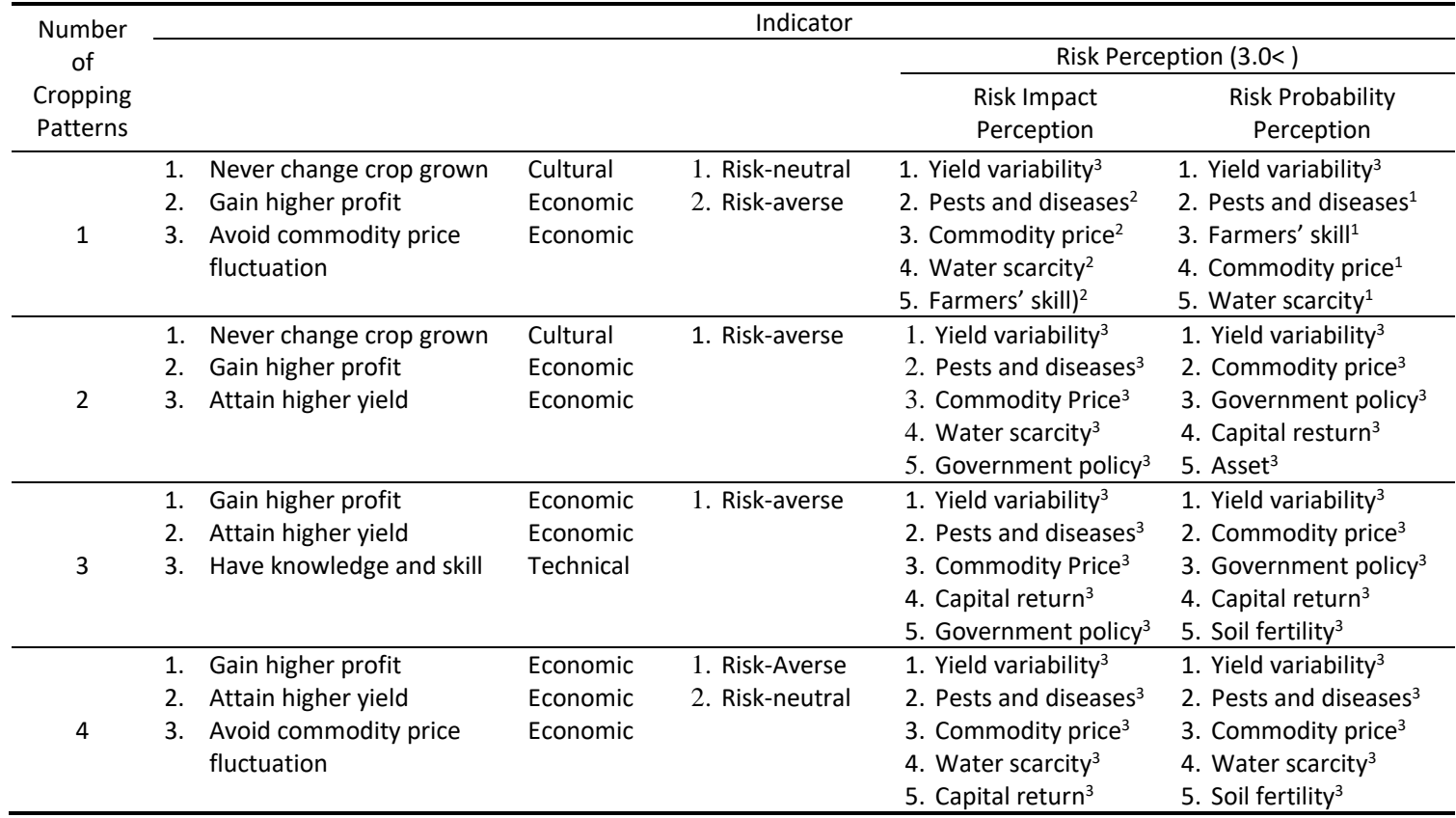

Note: ${ }^{1}=$ Likert scale score is below $2.0 ;{ }^{2}=$ Likert scale score ranged from $2.0-2.5 ;^{3}=$ Likert scale score was higher than 2.5 ; Likert scale: 1 = very low; 2 = low; 3 = high; 4 = very high.

(3) There were two variables that might influence the decision of farmers on practicing a single cropping pattern or four cropping patterns, which are motivation for farming and risk perception. Though 
they had similar risk behavior (risk-averse and risk-neutral), they differed in motivation for farming. As mentioned above, farmers who practiced a single cropping pattern were driven by both cultural and economic motivations, while farmers who practiced four cropping patterns were driven by economic motivation. Regarding risk perception, farmers who practiced four cropping patterns argued that "Capital return" risk impacted income from farming, and the probability of "Soil fertility" risk to occur was high. Those risks were not considered to be in the top five risks of farmers who practiced a single cropping pattern.

(4) The variable that might determine the decision of farmers to select two or three cropping patterns was motivation. Farmers who practiced two or three cropping patterns had similar risk behavior (risk-averse) and similar risk impact and risk probability perception, though different in the number of cropping patterns. This might be due to a difference in their motivations. Farmers who practiced two cropping patterns had cultural and economic motivations, while farmers who practiced three cropping patterns had economic and technical motivations.

(5) Farmer motivation for farming, risk behavior, and risk perception might influence the decision of farmers to practice two cropping patterns or four cropping patterns. Farmers who practiced two cropping patterns were driven by cultural and economic motivations, and the majority of them were risk-averse, while farmers who practiced four cropping patterns were only driven by economic motivations, and the majority of them were risk-neutral and risk- averse. Regarding risk perception, there were risks that were considered by farmers who practiced two cropping patterns as the top five risks, but they were not considered as such for farmers who practiced four cropping patterns, which are risk impact perception of "Government policy" and risk probability perception of "Government policy", "Capital return", and "Asset". Conversely, there were risks that were considered by farmers who practiced four cropping patterns to be in the top five risks, but they were not considered as such by farmers who practiced two cropping patterns, which are risk impact perception of "Capital return" and risk probability perception of "Commodity price", "Water scarcity", and "Soil fertility".

(6) Farmer motivation for farming and risk behavior might influence the decision of farmers to practice three or four cropping patterns. The majority of farmers who practiced three or four cropping patterns had a similar risk perception (impact and probability). However, because they differed in motivation and risk behavior, they selected different cropping patterns. Economic motivations encouraged farmers to practice four cropping patterns, while technical and economic motivations encouraged farmers to practice three cropping patterns. Regarding risk behavior, the majority of farmers who practiced three cropping patterns were risk-averse, while those who practiced four cropping patterns were risk-neutral and risk- averse.

To identify the farmer groups that had similar characteristics in motivation for farming, risk behavior, risk perception, and CEI, cluster analysis (CA) was conducted. Before conducting the CA, the PCA was applied to determine the common factors of farmer motivation for farming and risk perception. The result of varimax-rotated factor analysis (Table 10) shows that there were four common factors of farmer motivation for farming. These factors explained 73.48 percent of the variance. The factors were given a label based on the main motivations loaded on each factor: economic factor (F1), technical factor (F2), environmental factor (F3), and cultural factor (F4). Table 11 presents the result of varimax-rotated factor analysis of risk perception. The 11 perceptions of risk impact on income of farmers could be integrated into two factors, which accounted for 82.9 percent of the variance. The first factor was production and price (F1), while the second was farmer skill and government policy (F2). Similarly, the 11 perceptions of risk probabilities of farmers could be integrated into two factors, which covered 83.2 percent of the variance: the production factor $\left(F_{1}\right)$, and the farmer capacity and government policy factor (F2). 
Table 10. Rotated factor matrix of motivation for farming

\begin{tabular}{|c|c|c|c|}
\hline \multirow{2}{*}{ Motivation } & \multicolumn{3}{|c|}{ Factors } \\
\hline & Factor Loading & Variance Explained (\%) & Eigenvalues \\
\hline Economic (F1) & & 33.59 & 3.69 \\
\hline Gain higher profit & 0.518 & & \\
\hline Attain higher yield & 0.470 & & \\
\hline Avoid commodity price fluctuation & 0.518 & & \\
\hline Get higher cash flow & 0.312 & & \\
\hline Technical (F2) & & 17.06 & 1.88 \\
\hline $\begin{array}{l}\text { Reduce the occurrence of pests and } \\
\text { diseases }\end{array}$ & 0.651 & & \\
\hline Improve soil fertility & 0.667 & & \\
\hline Environmental (F3) & & 13.31 & 1.47 \\
\hline $\begin{array}{l}\text { Reduce the adverse impacts of the } \\
\text { environmental factor change }\end{array}$ & 0.662 & & \\
\hline Follow market demand & 0.660 & & \\
\hline Cultural (F4) & & 9.52 & 1.05 \\
\hline Never change the crop grown & -0.540 & & \\
\hline Avoid higher input cost & 0.443 & & \\
\hline Have knowledge and skill & 0.699 & & \\
\hline Total variance explained & & 73.48 & \\
\hline
\end{tabular}

Note: Factor loading taken is over 0.3 , and eigenvalues is over 1 . Kaiser-Meyer-Olkin of sampling adequacy $(\mathrm{KMO})=0.73$

Table 11. Rotated factor matrix of risk impact and risk probability

\begin{tabular}{|c|c|c|c|c|c|c|c|}
\hline \multirow{2}{*}{$\begin{array}{l}\text { Risk Impact } \\
\text { Perception }\end{array}$} & \multicolumn{3}{|c|}{ Factor } & \multirow[t]{2}{*}{$\begin{array}{c}\text { Risk Probability } \\
\text { Perception }\end{array}$} & \multicolumn{3}{|c|}{ Factor } \\
\hline & $\begin{array}{l}\text { Factor } \\
\text { Loading }\end{array}$ & $\begin{array}{c}\text { Variance } \\
\text { Explained } \\
(\%)\end{array}$ & $\begin{array}{l}\text { Eigen } \\
\text { values }\end{array}$ & & $\begin{array}{l}\text { Factor } \\
\text { Loading }\end{array}$ & $\begin{array}{c}\text { Variance } \\
\text { Explained } \\
(\%)\end{array}$ & $\begin{array}{l}\text { Eigen } \\
\text { values }\end{array}$ \\
\hline Production and price (F1) & & 71.96 & 7.92 & Production (F1) & & 67.60 & 7.44 \\
\hline Yield variability & 0.347 & & & Yield variability & 0.449 & & \\
\hline Pests and diseases & 0.327 & & & Pests and diseases & 0.435 & & \\
\hline Water scarcity & 0.324 & & & Water scarcity & 0.417 & & \\
\hline Soil fertility & 0.357 & & & Soil fertility & 0.382 & & \\
\hline Pollination failure & 0.337 & & & Pollination failure & 0.434 & & \\
\hline Commodity Price & 0.331 & & & Farmers' capacity and & & 15.64 & 1.72 \\
\hline Input price & 0.356 & & & $\begin{array}{l}\text { government policy } \\
\text { (F2) }\end{array}$ & & & \\
\hline Capital return & 0.367 & & & Farmers' skill & 0.550 & & \\
\hline Farmers' capacity and & & 10.94 & 1.20 & Asset & 0.418 & & \\
\hline government policy (F2) & & & & Government policy & 0.362 & & \\
\hline Farmers' skill & 0.779 & & & Capital return & 0.351 & & \\
\hline Asset & 0.458 & & & Commodity Price & 0.358 & & \\
\hline Government policy & 0.387 & & & Input price & 0.362 & & \\
\hline Total variance explained & & 82.90 & & $\begin{array}{l}\text { Total variance } \\
\text { explained }\end{array}$ & & 83.24 & \\
\hline
\end{tabular}

Note: Factor loading is over 0.3 and eigenvalues is over $1 . \mathrm{KMO}$ risk impact perception $=0.93, \mathrm{KMO}$ risk probability perception $=$ 0.89 .

Using the common factors of motivation for farming and risk perception (impact and probability) from the PCA, risk behavior, and the CEI, the farmers that had similar characteristics were grouped by the CA (Table 12 and Figure 10). Group 1 was farmers ( 8.75 percent of the total farmers) who had higher mean values for the cultural and economic motivations but lower technical and environmental motivations. In addition, they had low mean values of risk perception on both risk impact and risk probability (lower than 2.5). The mean value of the CEI and risk behavior of this group was 0.04 and Rp. 22,857 , respectively, suggesting that they were risk-takers and practiced a single cropping pattern. 
Table 12. Cluster analysis based on risk behavior, CEI, risk perception, and motivation

\begin{tabular}{|c|c|c|c|c|c|c|c|c|c|c|c|}
\hline \multirow{4}{*}{ Cluster } & \multicolumn{6}{|c|}{ Mean Values } & & & \multicolumn{3}{|c|}{ Number of Farmers } \\
\hline & \multirow[b]{3}{*}{$\mathrm{E}$} & \multirow[b]{3}{*}{$\mathrm{T}$} & \multirow[b]{3}{*}{ EV } & \multirow[b]{3}{*}{ CT } & \multirow{2}{*}{\multicolumn{2}{|c|}{ RI }} & & & \multirow[t]{3}{*}{$\mathrm{CP}$} & \multirow[t]{3}{*}{ No (\%) } & \multirow[t]{3}{*}{ Total } \\
\hline & & & & & & & \multicolumn{2}{|c|}{$\mathrm{RP}$} & & & \\
\hline & & & & & $\mathrm{P}$ & FCG & $\mathrm{P}$ & FCG & & & \\
\hline & & & & & & & & & 1 & 19 (90.5\%) & 21 \\
\hline & & & & & & & & & 2 & $1(4.8 \%)$ & (8.75\%) \\
\hline & & & & & & & & & 3 & $1(4.8 \%)$ & \\
\hline & & & & & & & & & 4 & $0(0 \%)$ & \\
\hline & & & & & & & & & 1 & $65(70.7 \%)$ & 92 \\
\hline & & & & & & & & & 2 & $5(5.4 \%)$ & (38.3\%) \\
\hline & & & & & & & & & 3 & $13(14.1 \%)$ & \\
\hline & & & & & & & & & 4 & $9(9.8 \%)$ & \\
\hline & & & & & & & & & 1 & $25(19.7 \%)$ & 127 \\
\hline & & & & & & & & & 2 & $36(28.35)$ & (52.9\%) \\
\hline & & & & & & & & & 3 & $51(40.2)$ & \\
\hline & & & & & & & & & 4 & $15(11.8 \%)$ & \\
\hline
\end{tabular}

Note: Cluster analysis uses hierarchical clustering method; CEI = Composite Entropy Index; RB = Risk behavior; MF = Motivation factor; $\mathrm{E}=$ Economic; $\mathrm{T}=$ Technical; $\mathrm{EV}=$ Environmental; $\mathrm{CT}=$ Cultural; $\mathrm{RPF}=$ Risk perception factor; $\mathrm{RI}=\mathrm{Risk}$ impact; $\mathrm{RP}=\mathrm{Risk}$ probability; $\mathrm{P}=$ Production and price; $\mathrm{FCG}=$ Farmers' capacity and government policy; $\mathrm{CP}=$ cropping pattern.

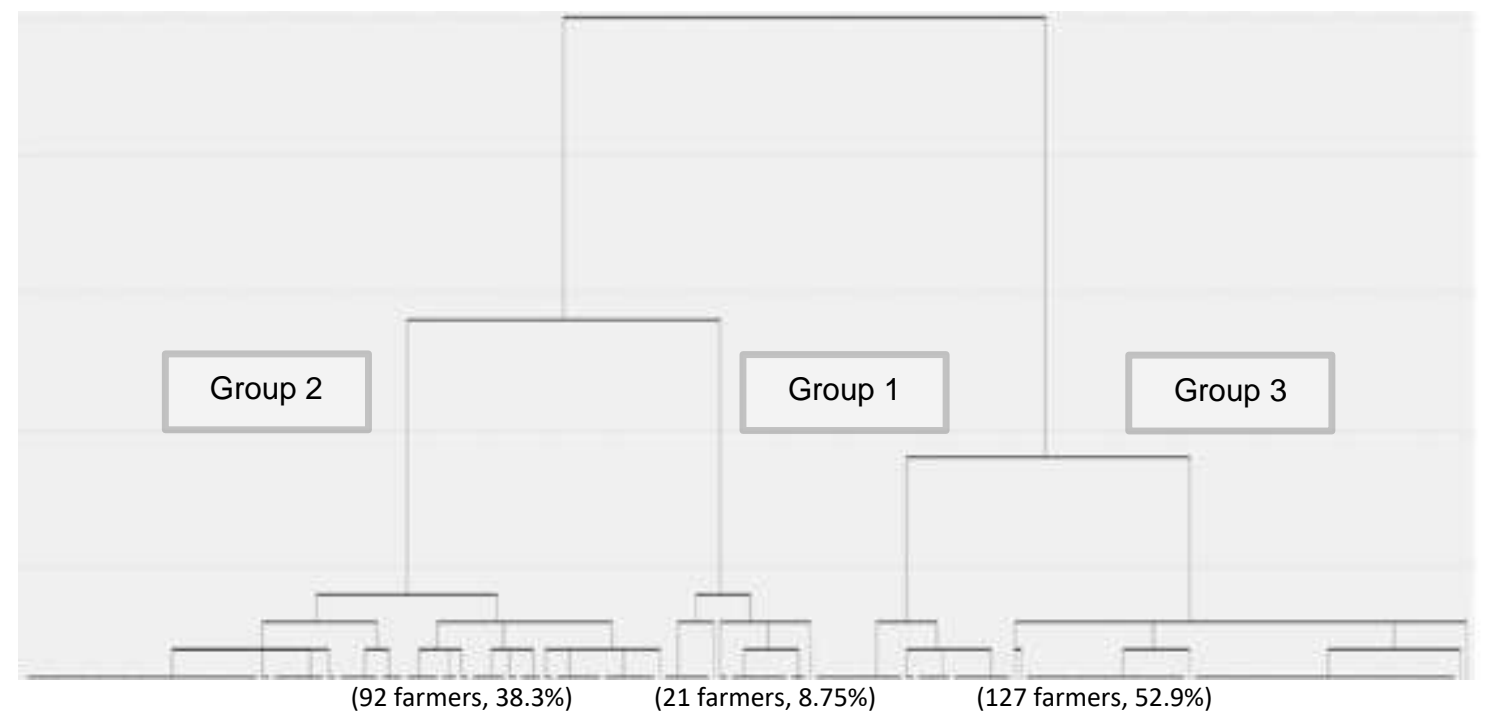

Figure 10. The dendrogram of CA

Group 2 was farmers (38.3 percent of the total farmers) who had a higher mean value for the economic and cultural motivations but lower technical and environmental motivations. The mean values of the economic motivation (0.38) and the cultural motivation (0.4) were slightly higher than those of Group 1. They had low mean values of risk perception, both risk impact and risk probability (lower than 2.5). Regarding risk behavior, they were risk-neutral, as their mean value of risk behavior was Rp. 11,304. The mean value of CEI (0.13) was higher than that of the CEI of Group 1, suggesting that Group 2 more diversified its cropping pattern than Group 1.

Group 3 was farmers (52.9 percent of the total farmers) who had a higher mean value for the economic and cultural motivations but lower technical and environmental motivations. The mean values of the economic motivation (0.49) and the cultural motivation (0.44) were slightly higher than those of Group 1 and Group 2. They had higher mean values of risk perception on both impact and probability perception (higher than 2.5) of production and price risk. They were risk- averse as they had a mean value of risk behavior of approximately Rp. 4,370. The mean value of CEI (0.28) was higher than those in Group 1 and 2, suggesting that Group 3 more diversified its cropping patterns than Group 1 and 2.

It can be found that the majority of farmers (77.1 percent, 84 out of 109 farmers) who practiced a single cropping pattern had low economic motivation as well as risk perception (impact and probability). The risk-neutral farmers dominated this group (59.6 percent, 65 out of 109 farmers). Meanwhile, the majority of farmers (77.9 percent, 102 out of 131 farmers) who practiced cropping pattern diversification 
had high economic motivation and risk perception (impact and probability), and they were risk-averse farmers (80.3 percent, 102 out of 127 farmers).

\section{Conclusions}

Economic motivation was the major reason for farmers practicing cropping pattern diversification, particularly for farmers who practiced three or four cropping patterns. "Knowledge and skills" was a key factor in practicing cropping pattern diversification. There was a tendency when farmers were risk-averse to diversify the cropping pattern. Meanwhile, the majority of risk-neutral and risk-taker farmers practiced a single cropping pattern. Moreover, this study revealed a relationship between the number of cropping patterns practiced by farmers and their risk perception. Farmers who practiced cropping pattern diversification had a higher risk impact and probability perception than those practicing a single cropping pattern (paddy-paddy- paddy).

As a whole, these are the characteristics of farmers who practiced cropping pattern diversification: (1) high-risk perception (impact and probability); (2) risk-averse; and (3) economic motivation. This implies that to adopt a risk-coping strategy, farmers should aware that there are risks that may impact farming income and motivate to increase their prosperity (economic motivation). In this study, around one-third of farmers had risk-neutral characteristics (92 farmers, 38.3 percent) and low-risk perception (impact and probability), of whom around 70.7 percent practiced single cropping pattern. They may not adopt any risk-coping strategies unless they are aware of the risks that they face. Improving awareness about the negative impacts of risks on income from farming might encourage them to adopt risk-coping strategies for both on-farm risk coping (such as cropping pattern diversification) and off-farm risk coping (such as agricultural insurance).

This study clarified the feature of farmer psychological characteristics (motivation, risk behavior, and risk perception) underlying their practical cropping patterns. Other farmer characteristics such as socioeconomic characteristics might also influence cropping patterns practiced by farmers. Therefore, it is necessary to integrate psychological and socio-economic characteristics (using a different framework) to find out how these characteristics influence cropping patterns (risk management) practiced by farmers in a future research.

\section{Acknowledgments}

The first author is grateful to the National Development Planning Agency (Bappenas) of the Republic of Indonesia for offering a scholarship for Ph.D. study at the Graduate School of International Development of Nagoya University.

\section{Reference}

Anderson, R., Dillon, J. L., \& Hardaker, J. B. (1988). Agricultural Decision Analysis (3rd ed.). Armidale, Australia: University of New England.

Asuransi Jasa Indonesia (Jasindo). (2017). Agricultural Insurance Customer Data. Jasindo. Unpublished.

Binswanger, H. P., \& Rosenzweig, M. R. (2007). Behavioural and material determinants of production relations in agriculture. The Journal of Development Studies, 22(3), 503-539. https://doi.org/10.1080/00220388608421994

Binswanger, H. P. (2012). Is there too much hype about index-based agricultural insurance? Journal of Development Studies, 48(2), 187-200.

Carter, M. R. (1997). Environment, technology, and the social articulation of risk in West African Agriculture. Economic Development and Cultural Change, 45(3), 557-590. DOI:10.1086/452291

Central Bureau of Statistics (CBS). (2016). Garut District in Figures. Garut, Indonesia: CBS of Garut Distritc.

Central Bureau of Statistics (CBS). (2017). West Java Province in Figures. Jakarta, Indonesia: CBS of West Java Province.

Chand, \& Ramesh. (1996). Diversification through high-value crops in Western Himalayan Region: Evidence from Himachal Pradesh. Indian Journal of Agricultural Economics, 51(4), 652-663.

Corbett, J. (1988). Famine and household coping strategies. World Development, 16(9), 1099-1112. https://doi.org/doi.org/10.1016/0305-750X(88)90112-X 
Di Falco, S., \& Chavas, J. P. (2009). On crop biodiversity, risk exposure, and food security in the highlands of Ethiopia. American Journal of Agricultural Economics, 91(3), 599-611. https://doi.org/10.1111/j.1467-8276.2009.01265.x

Feder, G. (1980). Farm size, risk aversion, and the adoption of new technology under uncertainty. Oxford Economic Papers, 32(2), 263-283. https://doi.org/10.1093/oxfordjournals.oep.a041479

Gasson, R. (1973). Goals and values of farmers. Journal of Agricultural Economics, 24(3), 521-542. DOI: 10.1111/j.1477-9552.1973.tb00952.x

Goetz, R. U., \& Zilberman, D. (2007). The economics of land-use regulation in the presence of an externality: A dynamic approach. Optimal Control Application and Methods, 28, 21-43. https://doi.org/doi.org/10.1002/oca

Greiner, R., Patterson, L., \& Miller, O. (2009). Motivations, risk perceptions, and adoption of conservation practices by farmers. Agricultural Systems, 99(2-3), 86-104. https://doi.org/10.1016/j.agsy.2008.10.003

Hardaker, J. B., Lien, G., Anderson, J. R., \& Huirne, R. B. M. (2015). Coping with Risk in Agriculture: Applied Decision Analysis (3rd ed.). Boston, USA: CABI.

Harwood, J, Heifner, R., Coble, K. H., Perry, J., \& Somwaru, A. (1999). Managing risk in farming: Concepts, research, and analysis. Washington, D.C, USA: U.S Departement of Agriculture.

Kabede, Y., \& Bogale, A. (1992). Risk behavior and new agricultural technologies: The case of producers in the central highlands of Ethiopia. Quarterly Journal of International Agriculture, 31, 510-520.

Kelley, T. G., \& Ryan, J. G. (1995). Applied participatory priority setting in international agricultural research: Making trade-offs transparent and explicit. Agricultural System, 49, 177-216. https://doi.org/10.1016/0308-521X(94)00030-U

Leemans, R., \& Born, J. V. D. (1994). Determining the potential distribution of vegetation, crops, and agricultural productivity. Water, Air, and Soil Pollution, 76(1-2), 133-161. https://doi.org/10.1007/BF00478338

Loomis, R. S., Williams, W. A., \& Hall, A. E. (1971). Agricultural productivity. Annual Review of Plant Physiology, 22, 431-468. DOI:10.1146/annurev.pp.22.060171.002243

Mandal, R. (2010). Cropping patterns and risk management in the flood plains of Assam. Economic and Political Weekly, 45(33), 78-81.

Mariano, M. J., Villano, R., \& Fleming, E. (2012). Factors influencing farmers' adoption of modern rice technologies and good management practices in the Philippines. Agricultural System, 110, 4153. https://doi.org/doi.org/10.1016/j.agsy.2012.03.010

Menezes, C., Geiss, C., \& Tressler, J. (1980). Increasing downside risk. The American Economic Review, 70(5), 921-932.

Moscardi, E., \& de Janvry, A. (1977). Attitudes toward risk among peasants: An economic approach. American Journal of Agricultural Economics, 59(4), 710-716. https://doi.org/doi.org/10.2307/1239398

National Disaster Management Authority (BNPB). (2017). Natural hazards in Indonesia. BNPB. Retrieved October 16, 2017, from http://dibi.bnpb.go.id

Naylor, R., Battisti, D., Vimont, D., \& Burke, M. (2007). Assessing risks of climate variability and climate change for Indonesian rice agriculture. Proceedings of the National Academy of Sciences of the United States of America, 104, 7752-7757.

O’Donoghue, E. J., Nigel, K., \& Roberts, M. J. (2005). Does risk matter for farm businesses? The effect of crop insurance on production and diversification. Presented at Annual Meeting of American Agricultural Economics Association on July 24-27, 2005, Providence, Rhode Island, USA. DOI:10.22004/ag.econ.19397

Rogers, R. W., \& Prentice-Dunn, S. (1997). Protection motivation theory. In Gochman, D.S. (Eds.), Handbook of health behavior research (Vol. 1, pp. 113-132). New York, USA: Plenum. 
Schechter, L. (2007). Traditional trust measurement and the risk confound: An experiment in rural Paraguay. Journal of Economic Behavior and Organization, 62(2), 272-292. https://doi.org/10.1016/j.jebo.2005.03.006

Shiyani, R., \& Pandya, H. (1998). Diversification of agriculture in Gujarat: A spatio-temporal analysis. Indian Journal of Agricultural Economics, 53(4), 627-639. DOI:10.22004/ag.econ.297638

Supari, Salimun, E., Aldrian, E., Sopaheluwakan, A., Juneng, L., \& Tangang, F. (2018). ENSO modulation of seasonal rainfall and extremes in Indonesia. Climate Dynamics, 51(7-8), 2559-2580. https://doi.org/doi.org/10.1007/s00382-017-4028-8

The Ministry of Agriculture of the Republic of Indonesia (MoA). (2017). Statistics of Climate, Crop Pests and Diseases, and Climate Change Impact 2012-2014. Jakarta, Indonesia: The Ministry of Agriculture of the Republic of Indonesia.

The Ministry of Agriculture of the Republic of Indonesia (MoA). (2018). The evaluation of rice and livestock insurance in 2018. Presented at the Evaluation of Agricultural Insurance Implementation on May 16, 2018, the Ministry of Agriculture, Jakarta, Indonesia.

Zimmerman, F. J., \& Carter, M. R. (2003). Asset smoothing, consumption smoothing, and the reproduction of inequality under risk and subsistence constraints. Journal of Development Economics, 71, 233260. https://doi.org/doi.org/10.1016/S0304-3878(03)00028-2 